\title{
Faktor-Faktor yang Mempengaruhi Produksi Usahatani Kacang Tanah di Desa Sunsea Kecamatan Naibenu Kabupaten Timor Tengah Utara
}

\author{
Kristina Kolo ${ }^{\mathrm{a}}$, Simon Juan Kune \\ ${ }^{a}$ Fakultas Pertanian, Universitas Timor, Kefamenanu, Indonesia. \\ ${ }^{b}$ Fakultas Pertanian, Universitas Timor, Kefamenanu, Indonesia.
}

\section{Article Info}

Article history:

Received 15 Mei 2016

Received in revised form 4 Juni 2016

Accepted 25 Juli 2016

\section{Keywords:}

Usahatani Kacang Tanah

Sunsea

Naibenu

\section{Abstrak}

Tujuan dari penelitian ini adalah untuk mengetahui gambaran usahatani kacang tanah dan faktor - faktor yang mempengaruhi usahatan kacang tanah. Metode analisis data yang digunakan metode deskriptif kualitatif dan model analisis Cobb-Douglas. Gambaran usahatani kacang tanah di desa penelitian dimulai dari tahap persiapan benih, pembersihan dan pengolahan lahan, penanaman, penyiangan yan dilakukan dengan dua tahap, panen dan pasca panen. Pada uji F, faktor modal, luas lahan, benih, tenaga kerja, pengalaman usahatani, pendidikan petani secara bersama-sama (simultan) berpengaruh nyata terhadap produksi kacang tanah. Sedangkan pada uji $\mathrm{T}$, secara sendiri- sendiri (parsial) faktor luas lahan, benih memiiki pengaruh yang positif dan signifikan terhadap produksi usahatani kacang tanah Sedangkan pngalaman usahatani, pendidikan, modal, tenaga kerja tidak berpengaruh terhadap produksi usahatani kacang tanah. Nilai Kofisien Determinasi $\left(\mathrm{R}^{2}\right)$ sebesar 0.675 atau mencapai $67,5 \%$, angka tersebut menunjukkan bahwa kemampuan variabel bebas dalam memberikan informasi untuk menjelaskan keragaman variabel terikat relatif tinggi. Hasil tersebut dapat disimpulkan bahwa variabe independen memiliki pengaruh sebesar $67,5 \%$ terhadap peningkatan maupun penurunan produksi sedangkan sisanya 32,5\% dijelaskan oleh faktor lain diluar faktor yang diteliti. (O2016 dipublikasikan oleh Agrimor.

\section{Pendahuluan}

Indonesia merupakan salah satu negara berkembang dengan mayoritas penduduknya menggantungkan hidup pada sektor pertanian sebagai sumber mata pencaharian. Kenyataannya didukung dengan sebagian besar penggunaan wilayah di Indonesia diperuntukan sebagai lahan pertanian dan hampir 50\% dari total angkatan kerja masih menguntungkan nasibnya bekerja disektor pertanian (Sapto, 2004)

Agribisnis meliputi segala kegiatan yang berhubungan dengan pengusahaan tumbuhan dan hewan ( komoditas pertanian, peternakan, perikanan dan kehutanan) yang berorientasi pasar. Di Indonesia sejak dilaksanakan pembangunan pertanian, telah diterapkan beberapa sistem pengembangan pertanian berskala usaha baik untuk komoditi pangan maupun non pangan (Darius, 2010).

Salah satu komoditi tanaman pangan yang memiliki prospek sangat baik untuk dikembangkan adalah kacang tanah, dengan melihat kondisi saat in dimana permintaan kacang tanah meningkat seiring dengan banyak produk produk makanan yang menjadikan kacang tanah sebagai bahan baku pokok, baik yang diawetkan/ instan atau makanan lainnya (Makmur, 2011).

Kacang tanah merupakan tanaman pangan yang telah banyak dibudidayakan oleh petani sebagai tanaman palawija, dan memiliki manfaat sehingga prospek pengembangan kacang tanah di Indonesia sangat baik.

Kacang tanah mengandung lemak $45 \%$ dan protein $27 \%$. Protein yang terdapat didalam kacang tanah jauh lebih tinggi dibandingkan protein yang berasal dari daging dan telur, juga terdapat zat besi, vitamin $\mathrm{E}$ dan kalsium, vitamin B kompleks dan Fosforus, vitamin A dan K, lesitin, kolin dan kalsium. Dimana semua zat yang terkandung dalam upaya meningkatkan pertumbuhan, mencerdaskan, hingga upaya membina ketahanan tubuh dalam mencegah beberapa penyakit. (Vyan, 2009).

Kabupaten TTU memiliki luas daerah panen tanaman Kacang Tanah yang tersebar pada 24 (dua puluh empat) Kecamatan dengan tingkat produksi pada tahun 2010-2013 yaitu pada tahun 2010 luas daerah panen $2.704 \mathrm{Ha}$, tahun 2011 luas daerah panen $2.344 \mathrm{Ha}$, tahun 2012 luas daerah panen 0, tahun 2013 luas daerah panen $1.182 \mathrm{Ha}$. Dengan jumlah produksi tahun 2010 yaitu 985 ton, tahun 2011 yaitu 2.864 ton, tahun 2012 yaitu 0 dan pada tahun 2013 yaitu 1.369 ton (BPS kab. TTU 2014). Dari data diatas dapat kita lihat luas lahan panen Kacang Tanah setiap tahun berbeda dengan tingkat produksi yang berbeda-beda.

Kecamatan Naibenu memiliki 4 (empat) desa diantaranya Desa Sunsea. Mayoritas penduduk menggantungkan hidup pada hasil pertanian, misalnya pad ladang, ubi, jagung dan kacang tanah. Namun Desa Sunsea memiliki potens besar dalam mengembangkan tanaman kacang tanah karena didukung oleh tersedianya sumber daya manusia sebagai pelaku usaha tani kacang tanah, sumber daya lahan yang cukup potensial yang memungkinkan untuk mengembangkan kacang tanah, adanya saluran pemasaran hasil produksi kacang tanah ke Kabupaten TTU dengan bantuan dari yayasan Mitra Tani Mandir (YMTM). Usaha tani kacang tanah diusahakan pada pertengahan bulan januari, dan dari hasil produksi yang di peroleh sebagian besar dijual, sisanya dikonsums dan dijadikan bibit untuk musim tanam berikutnya.

Produksi kacang tanah Desa Sunsea pada tahun 2011 dengan luas lahan 21 Ha tingkat produksi 24 ton kacang tanah, tahun 2012 luas lahan $21 \mathrm{Ha}$ dengan produksi 22 ton, tahun 2013 luas lahan 23 Ha dengan produksi 27 ton, pada ahun 2014 luas lahan 25 Ha dengan tingkat produksi 31 ton. (Data Desa Sunsea).

\section{Metode}

Penelitian dilaksanakan pada bulan Oktober 2015 sampai bulan Februari 2016 di Desa Sunsea, Kecamatan Naibenu Timur Kabupaten Timor Tengah Utara. Pengumpulan data dilakukan dengan metode survei. Dimana data yang dikumpulkan berupa data primer dan data sekunder. Data primer adalah datadata yang diperoleh melaui wawancara dengan responden berdasarkan daftar pertanyaan yang disiapkan sebelumnya, sedangkan data sekunder adalah data yang diperoleh dan instansi terkait. Pengambilan sampel dilakukan secara acak (Simple Random Sampling) dengan total sampel sebanyak 70 orang.

Variabel yang digunakan dalam penelitian ini adalah modal, luas lahan, benih ,tenaga kerja, pengalaman petani, dan pendidikan petani. Untuk mengetahui gambaran umum usahatani digunakan metode analisis deskriptif kualitatif. Untuk mengetahui faktor-faktor yang menpengaruhi produksi kacang tanah digunakan Cobb-Douglass sesuai petunjuk Soekartawi, (2003).

\section{Hasil dan Pembahasan \\ 3.1 Deskripsi Usahatani Kacang Tanah}

Usahatani Kacang Tanah di lokasi penilitian memiliki luas lahan yang berbeda - beda berkisar antara 20 - 50 are. Usahatani kacang tanah ada yan monokultur atau hanya kacang tanah sendiri yang ditanam pada lahan yang ada namun ada juga yang tumpang sari atau selain kacang tanah ada juga tanaman lain yang dibudidayakan pada lahan tersebut. Lahan yang ditanami kacang tanah berada dekat jalur transportasi dan pemukiman sehingga memudahkan petan dalam pengangkutan hasil produksi. Di lokasi penelitian masyarakat banyak yang membudidayakan kacang tanah karena selain secara turun temurun, desa Sunsea memiliki lahan yang baik untuk budidaya tanaman kacang tanah, tidak memerlukan banyak biaya dalam membudidayakan kacang tanah dan harga kacang tanah dipasaran cukup menguntungkan bagi petani dengan harga perkilo Rp 17.000/kg isi dan Rp 12.000/kg glondongan atau kulit.

Usahatani Kacang Tanah yang dilakukan di lokasi penelitian yaitu antara lain persiapan benih, pembersihan dan pengolahan lahan, penanaman, pemeliharaan, panen dan pasca panen

1. Persiapan Benih

Benih yang digunakan yaitu Kacang Tanah yang masih ada kulitnya yang telah disimpan setelah panen tahun sebelumnya, ada juga benih yang dibeli, Kacang Tanah tersebut dikupas kemudian di sortir dengan memilih benih yang baik untuk di tanam, ciri benih yang baik yang di gunakan petani di lokasi penelitian yaitu berbiji besar dan tidak rusak. Benih yang disiapkan berdasarkan luas lahan yang akan ditanam. Setelah disortir benih tersebut dimasukkan kembali ke dalam karung atau bakul kemudian disimpan di daerah yang kering dan kebanyakan petani menempatkan kacang tanah dekat api sehingga benih yang dipersiapkan tidak rusak. Persiapan benih dilakukan satu minggu sebelum ditanam.

2. Pembersihan dan Pengolahan lahan

Pembersihan lahan dilakukan pada bulan september - awal oktober Pembersihan lahan dimulai dengan membuat pagar atau memperbaiki pagar yang ada namun telah rusak, kemudian dilanjutkan dengan menebas atau memotong tumbuhan yang hidup dalam area lahan yang akan ditanami, setelah itu lahan didiamkan selama 2 - 3 minggu sambil menunggu dedaunan yang sebelumnya ditebas kering sehingga bisa dilakukan pembakaran. Lahan didiamkan sambil menunggu hujan.

3. Penanaman

Penanaman dilakukan pada pertengahan bulan januari, petani membuat lubang tanam pada lahan dengan cara ditugal dengan jarak $40 \times 20 \mathrm{~cm}$, menggunakan sebatang kayu dengan panjang minimal 1 meter. setiap lubang tanam di masukan 2 biji kacang tanah setelah itu lubang tersebut ditutup kembali menggunakan tanah.

4. Pemeliharaan

Setelah melakukan penanaman, kacang tanah mulai tumbuh atau berkecambah pada umur $4-7$ hari setelah tanam. Tahap selanjutnya yaitu pemeliharaan yang dilakukan 2 kali yaitu tahap pertama penyiangan gulma pada umur tanaman 2- 3 minggu, dengan menggunakan linggis kecil (tofa) penyiangan tahap pertama bertujuan untuk membersikan gulma dan menggembur tanah sehingga akar dari tanaman kacang tanah dapat tumbuh degan baik. Tahap kedua penyiangan gulma dilakukan pada umur kacang tanah 
40-50 hari dengan tujuan pembersihan gulma agar tidak mengganggu kacang tanah pada tahap pengisian polong.

5. Panen dan Pasca Panen

Pemanenan dilakukan setelah Kacang Tanah berumur 100 hari(3 bulan), kacang tanah digali kemudian dipisahkan dari daun dan batangnya. Hasil dari kacang yang dipanen kemudian disortir, bagian dari kacang tanah yang rusak dipisahkan dari bagian kacang tanah yang baik.

Kacang tanah di jemur selama 3-4 hari. Kemudian akan dilakukan penyortiran tahap kedua dengan tujuan memisahkan kacang yang berisi dan tidak berisi. Setelah itu kacang tanah dimasukkan kedalam karung atau bakul kemudian disimpan di tempat yang kering atau yang berada dekat api sehingga kacang tanah tidak rusak. Sebagian kacang tanah dijual atau dikonsumsi.

\subsection{Faktor Produksi}

Fungsi produksi yang diperoleh menggambarkan hubungan antara faktor produksi yang diduga berpengaruh $(\mathrm{X})$ terhadap produksi usahatani Kacang Tanah (Y). Analisis korelasi merupakan langkah awal untuk melihat pengaruh suatu variabel bebas terhadap variabel terikat. Kriteria yang digunakan untuk mengukur pengaruh variabel bebas terhadap variabel terikat yaitu angka korelasi yang serius $(<0.05)$ maka dapat dilanjutkan pada analisis cobb-douglas. Berikut ini akan ditampilkan hasil analisis korelasi.

\section{Tabel 1, Matriks Korelasi}

\begin{tabular}{|c|c|c|c|c|c|c|c|c|}
\hline & & $\mathrm{Y}$ & $\mathrm{X} 1$ & $\mathrm{X} 2$ & $\mathrm{X} 3$ & $\mathrm{X} 4$ & $\mathrm{X} 5$ & $\mathrm{X} 6$ \\
\hline \multirow[t]{3}{*}{$\bar{Y}$} & Pearson Correlation & 1 & -.211 & $.993^{* *}$ & $.773^{* *}$ & -.149 & .249 & -.220 \\
\hline & Sig. (2-tailed) & & .079 & .000 & .000 & .219 & .038 & .067 \\
\hline & $\mathrm{N}$ & 70 & 70 & 70 & 70 & 70 & 70 & 70 \\
\hline \multirow[t]{3}{*}{$\mathrm{X} 1$} & Pearson Correlation & -.211 & 1 & -.222 & -.069 & $.445^{* *}$ & .026 & .076 \\
\hline & Sig. (2-tailed) & .079 & & .064 & .572 & .000 & .832 & .533 \\
\hline & $\mathrm{N}$ & 70 & 70 & 70 & 70 & 70 & 70 & 70 \\
\hline \multirow[t]{3}{*}{$\mathrm{X} 2$} & Pearson Correlation & $.993^{* *}$ & -.222 & 1 & $.761^{* *}$ & -.172 & .241 & -.226 \\
\hline & Sig. (2-tailed) & .000 & .064 & & .000 & .155 & .044 & .060 \\
\hline & $\mathrm{N}$ & 70 & 70 & 70 & 70 & 70 & 70 & 70 \\
\hline \multirow[t]{3}{*}{$\mathrm{X} 3$} & Pearson Correlation & $.773^{* *}$ & -.069 & $.761^{* *}$ & 1 & -.076 & .058 & -.019 \\
\hline & Sig. (2-tailed) & .000 & .572 & .000 & & .532 & .634 & .874 \\
\hline & $\mathrm{N}$ & 70 & 70 & 70 & 70 & 70 & 70 & 70 \\
\hline \multirow[t]{3}{*}{$\mathrm{X} 4$} & Pearson Correlation & -.149 & $.445^{* * *}$ & -.172 & -.076 & 1 & .137 & .042 \\
\hline & Sig. (2-tailed) & .219 & .000 & .155 & .532 & & .258 & .733 \\
\hline & $\mathrm{N}$ & 70 & 70 & 70 & 70 & 70 & 70 & 70 \\
\hline \multirow[t]{3}{*}{$\mathrm{X} 5$} & Pearson Correlation & .249 & .026 & .241 & .058 & .137 & 1 & $330^{* *}$ \\
\hline & Sig. (2-tailed) & .038 & .832 & .044 & .634 & .258 & & .000 \\
\hline & $\mathrm{N}$ & 70 & 70 & 70 & 70 & 70 & 70 & 70 \\
\hline \multirow[t]{3}{*}{$\mathrm{X} 6$} & Pearson Correlation & -.220 & .076 & -.226 & -.019 & .042 & $.330^{* *}$ & 1 \\
\hline & Sig. (2-tailed) & 067 & .533 & .060 & .874 & .733 & .000 & \\
\hline & $\mathrm{N}$ & 70 & 70 & 70 & 70 & 70 & 70 & 70 \\
\hline
\end{tabular}

Sumber: Data Primer Diolah, 2016

Dari Tabel 1. di atas dapat dilihat hubungan antara variabel jika nilai signifikansi $<0,05$ maka terdapat korelasi, sebaliknya jika nilai signifikansi $>$ 0,05 maka tidak terdapat korelasi. Jika terdapat tanda bintang pada person correlation maka antara variabel yang dianalisis terjadi korelasi. Sebaliknya jika tidak terdapat tanda bintang pada person correlation maka antara variabel yang dianalisis tidak terjadi korelasi. Selain besarnya korelasi, tanda korelasi juga berpengaruh pada hasil yang diperoleh, pada tabel diatas terdapat nilai negatif () yang berarti pada variabel terdapat nilai yang berlawan atau tidak signifikan, sedangkan yang bertanda positif (+) menunjukkan antara variabel menunjukkan arah yang sama atau signifikan.

\subsection{Analisis Cobb-Douglas}

Analisis yang digunakan pada penelitian ini adalah analisis regresi berganda dalam bentuk logaritma dengan fungsi produksi Cobb-Douglas.

Tabel 2. Analisis Varians

\begin{tabular}{ccccrrr}
\hline \multirow{2}{*}{ Model } & \multicolumn{2}{c}{$\begin{array}{l}\text { Unstandardized } \\
\text { Coefficients }\end{array}$} & $\begin{array}{c}\text { Standardized } \\
\text { Coefficients }\end{array}$ & \multirow{2}{*}{ t } & \multirow{2}{*}{ Sig. } \\
\cline { 2 - 4 } & \multicolumn{1}{c}{$\mathrm{B}$} & Std. Error & Beta & & \\
\hline (Constant) & 2.802 & .349 & & 8.039 & .000 \\
\hline $\mathrm{X} 1$ & -.016 & .067 & -.004 & -.239 & .812 \\
\hline $\mathrm{X} 2$ & .981 & .025 & .961 & 38.607 & .000 \\
\hline $\mathrm{X} 3$ & .034 & .019 & .042 & 1.802 & .076 \\
\hline $\mathrm{X} 4$ & .015 & .012 & .019 & 1.203 & .233 \\
\hline $\mathrm{X} 5$ & .011 & .014 & .013 & .797 & .428 \\
\hline $\mathrm{X} 6$ & .001 & .014 & .002 & .102 & .919 \\
\hline
\end{tabular}

Sumber: Data Primer Diolah, 2016
Fungsi Cobb - Douglas digunakan untuk menguji pengaruh antara variabel independen terhadap produksi Kacang Tanah. Dari angka korelasi pada tabel kemudian dilakukan model pendugaan dengan cara regresi yang hasilnya disajikan pada Tabel 2.

Berdasarkan Tabel 2. dapat diperoleh hasil dari fungsi cobb - douglas sebagai berikut :

$\operatorname{Ln} Y=\operatorname{Ln} 2.802-0.004 \operatorname{Ln} X_{1}+0.961 \operatorname{Ln} X_{2}+0.042 \operatorname{Ln} X_{3}+0.019 \operatorname{Ln} X_{4}+0.013$ $\operatorname{Ln} X_{5}-0.002 \operatorname{Ln} X_{6}$

\subsection{Uji F}

Uji F dilakukan untuk melihat bagaimana variabel independen (modal, luas lahan, benih, tenaga kerja, pengalaman usahatani, pendidikan petani) secara bersama-sama atau simultan mempengaruhi variabel dependen (faktor produksi kacang tanah) dengan membandingkan rata-rata kuadrat regresi dengan rata-rata kuadarat residu dan hasilnya dapat dilihat dalam Tabel 3.

\begin{tabular}{lrrlcc}
\multicolumn{6}{l}{ Tabel 3. Analisis $\mathrm{F}_{\text {hitung }}$} \\
\multicolumn{1}{c}{ Model } & $\begin{array}{c}\text { Jumlah } \\
\text { Kuadrat }\end{array}$ & $\begin{array}{c}\text { Jumlah } \\
\text { Rerata }\end{array}$ & Df & $\mathrm{F}_{\text {hitung }}$ & \multicolumn{1}{c}{$\mathrm{F}_{\text {tabel }}$} \\
\hline Regression & 4.498 & 6 & .750 & 814.448 & $2.36(5 \%)$ \\
Residual & .058 & 63 & .001 & & \\
Total & 4.556 & 69 & & & \\
\hline
\end{tabular}

\section{Sumber: Data Primer Diolah, 2016}

Berdasarkan Tabel 3. maka dapat diketahui bahwa rata-rata regresi $=6$, dan rata-rata residu $=63$, maka $\mathrm{F}_{\text {hitung }}=69$. Dari tabel dapat dijelaskan bahwa $\mathrm{F}_{\text {hitung }}(814.448)>\mathrm{F}_{\text {tabel }}(2,36)$ berdasarkan hasil olahan data tersebut dapat dikatakan bahwa variabel bebas yang meliputi Modal, Luas lahan, Benih, tenaga kerja, pengalaman usahatani, pendidikan petani secara bersama - sama memiliki pengaruh nyata terhadap produksi kacang tanah.

\subsection{Uji t}

Uji t dilakukan untuk mengetahui pengaruh variabel bebas yang diteliti secara individual terhadap produksi Kacang Tanah di Desa Sunsea. Maka digunakan uji statistik $\mathrm{t}$ dengan membandingkan $\mathrm{t}$ tabel dengan $\mathrm{t}$ hitung dengan asumsi $\mathrm{H}_{0}$ ditolak apabila $\mathrm{t}_{\text {hitung }}>\mathrm{t}_{\text {tabel }}$ atau $\mathrm{H}_{1}$ diterima apabila $\mathrm{t}_{\text {hitung }}<\mathrm{t}_{\text {tabel, }}$ berdasarkan kriteria penerimaan atau penolakan hipotesis dengan tingkat kepercayaan $95 \%$ adalah sebagai berikut :

$\mathrm{H}_{0}$ : Tidak ada pengaruh signifikan antara masing - masing variabel idependen $(\mathrm{X})$ terhadap variabel dependen $(\mathrm{Y})$

$\mathrm{H}_{1}$ : Ada pengaruh signifikan antara masing - masing variabel independen (X) terhadap variabel dependen (Y), Hasil analisis dapat dilihat pada Tabel 4.

\begin{tabular}{|c|c|c|c|c|c|c|}
\hline & \multirow[t]{2}{*}{ Model } & \multicolumn{2}{|c|}{$\begin{array}{c}\text { Unstandardized } \\
\text { Coefficients }\end{array}$} & \multirow{2}{*}{$\begin{array}{c}\text { Standardized } \\
\text { Coefficients } \\
\text { Beta }\end{array}$} & \multirow[t]{2}{*}{$\mathrm{T}_{\text {hitung }}$} & \multirow[t]{2}{*}{$\mathrm{T}_{\text {tabel }}$} \\
\hline & & B & Std. Error & & & \\
\hline \multirow[t]{7}{*}{1} & (Constant) & 2.802 & .349 & & 8.039 & 1.671 \\
\hline & $\mathrm{X} 1$ & -.016 & .067 & -.004 & -.239 & \\
\hline & $\mathrm{X} 2$ & .981 & .025 & .961 & 38.607 & \\
\hline & $\mathrm{X} 3$ & .034 & .019 & .042 & 1.802 & \\
\hline & $\mathrm{X} 4$ & .015 & .012 & .019 & 1.203 & \\
\hline & $\mathrm{X} 5$ & .011 & .014 & .013 & .797 & \\
\hline & X6 & .001 & .014 & .002 & .102 & \\
\hline
\end{tabular}

\section{Sumber: Data Primer Diolah, 2016}

Tabel 4. terlihat jelas perhitungan $t$ dan selanjutnya akan diuji pengaruh secara parsial dari faktor Modal, Luas lahan, Benih, tenaga kerja, pengalaman usahatani, pendidikan petani terhadap produksi kacang tanah.

a. Modal $\left(\mathrm{X}_{1}\right)$

Secara parsial hasil perhitungan menunjukkan bahwa $t_{\text {hitung }}(-0.239)<\mathrm{t}_{\text {tabel }}$ (1.671) dengan demikian faktor modal dikatakan memiliki pengaruh yang negatif terhadap produksi usahatani kacang tanah. Diduga penggunaan modal oleh petani sudah melampaui batas sehingga ketika terjadi penambahan 1 satuan input pada modal akan mengakibatkan pengurangan produksi sebesar 0,239 satuan. Dengan demikian hipotesi $\mathrm{H}_{0}$ di terima dan $\mathrm{H}_{1}$ di tolak.

b. Luas Lahan $\left(\mathrm{X}_{2}\right)$

Secara parsial hasil perhitungan menunjukkan bahwa $t_{\text {hitung }}(38.607)>t_{\text {tabel }}$ (1.671) dengan demikian faktor luas lahan dikatakan memiliki pengaruh yang positif dan sangat nyata terhadap produksi usahatani kacang tanah. Artinya bahwa ketika luas lahan ditambah akan meningkatkan produksi sebesar 38.607 satuan. Dengan demikian maka hipotsis $\mathrm{H}_{1}$ di terima dan $\mathrm{H}_{0}$ di tolak karena terdapat pengaruh luas lahan terhadap produksi kacang tanah. c. Benih $\left(\mathrm{X}_{3}\right)$

Secara parsial hasil perhitungan menunjukan bahwa $t_{\text {hitung }}(1.802)>t_{\text {tabe }}$ (1.671) dengan demikian faktor benih dikatakan memiliki pengaruh yang positif terhadap produksi usahatani kacang tanah. Artinya bahwa ketika benih ditambah akan meningkatkan produksi sebesar 1.802 satuan. Namun hal ini juga harus disesuaikan dengan kondisi lahan yang ada. Dengan demikian maka hipotesis $\mathrm{H}_{1}$ 
di terima dan $\mathrm{H}_{0}$ ditolak karena terdapat pengaruh benih terhadap produksi kacang tanah.

d. Tenaga Kerja $\left(\mathrm{X}_{4}\right)$

Secara parsial hasil perhitungan menunjukan bahwa $t_{\text {hitung }}(1.203)<t_{\text {tabel }}$ (1.671) dengan demikian faktor tenaga kerja dikatakan tidak berpengaruh secara positif terhadap produksi usahatani kacang tanah. Tenaga kerja petani yang diteliti belum optimal sehingga mempengaruhi penurunan produksi kacang tanah. Jika penambahan $1 \%$ tenaga kerja maka akan meningkatkan produksi sebesar 1.203 persen. Dengan demikian hipotesi $\mathrm{H}_{1}$ di tolak dan $\mathrm{H}_{0}$ di terima.

e. Pengalaman Usahatani $\left(\mathrm{X}_{5}\right)$

Hasil perhitungan menunjukan bahwa $t_{\text {hitung }}(0.797)<\mathrm{t}_{\text {tabel }}(1.671)$ maka faktor pengalaman usahatani dikatakan memiliki pengaruh positif terhadap produksi usahatani kacang tanah. Pengalaman usahatani responden yang diteliti paling banyak 26 - 30 tahun dan teknik dalam berusahatani masih menggunakan cara tradisional dan turun - temurun berdasarkan keadaan seperti ini akan sulit bagi petani dalam menerima teknologi seperti saat ini sehingga mempengaruhi hasil produksi kacang tanah. Hal ini menunjukkan semakin banyak pengalaman petani maka akan meningkatkan produksi yang dihasilkan. Jika terjadi penabahan $1 \%$ pengalaman Usahatani maka akan meningkatkan produksi sebesar 0.797 persen Dengan demikian hipotesi $\mathrm{H}_{1}$ di tolak dan $\mathrm{H}_{0}$ di terima.

f. Pendidikan Petani $\left(\mathrm{X}_{6}\right)$

Secara parsial hasil perhitungan diatas menunjukkan bahwa $t_{\text {hitung }}(0.102)<$ $\mathrm{t}_{\text {tabel }}(1.671)$ maka faktor pendidikan petani dikatakan memiliki pengaruh secara positif terhadap usahatani kacang tanah. Di duga minimnya tingkat pendidikan petani sehingga mempengaruhi produksi kacang tanah. kebanyakan pendidikan responden yang diteliti yaitu pada tingkat SD sehingga dengan rendahnya tingkat pendidikan petani sangat mempengaruhi produksi kacang tanah. Jika terjadi penambahan $1 \%$ pendidikan petani maka akan meningkatkan produksi sebesar 0.102 persen. Dengan demikian hipotesi $\mathrm{H}_{1}$ di tolak dan $\mathrm{H}_{0}$ di terima.

\subsection{Koefisien Determinasi $\left(\boldsymbol{R}^{2}\right)$}

Uji koefisien determinasi $\left(\mathrm{R}^{2)}\right.$ digunakan untuk melihat seberapa besar variabel idependen ( modal, luas lahan, benih, tenaga kerja, pengalaman usahatani, pendidikan petani) menjelaskan variabel dependen (produksi).

Tabel 5. Analisis Koefisien Determinasi $\left(\mathrm{R}^{2}\right)$

\begin{tabular}{cccc}
$\mathrm{R}$ & $\mathrm{R}^{2}$ & $\mathrm{R}^{2}$ biasa & Std. Error estimasi \\
\hline $.822^{\mathrm{a}}$ & .675 & .674 & .03034 \\
\hline
\end{tabular}

Dalam penelitian ini, nilai $\mathrm{R}^{2}$ sebesar 0.675 atau mencapai $67,5 \%$, angka tersebut menunjukkan bahwa kemampuan variabel bebas dalam memberikan informasi untuk menjelaskan keragaman variabel terikat relatif tinggi. Hasil tersebut dapat disimpulkan bahwa variabel independen (Modal, Luas lahan, Benih, tenaga kerja, pengalaman usahatani, pendidikan petani) memiliki pengaruh sebesar $67,5 \%$ terhadap peningkatan maupun penurunan produksi sedangkan sisanya $32,5 \%$ dijelaskan oleh faktor lain diluar faktor yang diteliti.

\section{Simpulan}

Usahatani Kacang Tanah diawali dengan 1) Persiapan Beni, benih dipersiapkan dengan memilih benih yang baik untuk ditanam. 2) pembersihan dan Pengolahan lahan, pembersihan lahan dilakukan pada bulan september awal oktober. Kacang Tanah ditanam pada pertengahan bulan januari, pembersihan lahan dilakukan dengan sistem tebas bakar dan pembuatan pagar. 3) Penanaman, dilakukan setelah selesai pembersihan lahan dengan cara ditugal, jarak $40 \times 20 \mathrm{~cm}$. 4) Pemeliharaan, dilakukan 2 kali yaitu penyiangan gulma pertama pada umur 2- 3 minggu, penyiangan gulma kedua dilakukan pada umur kacang tanah 40-50 hari. 5) Panen dan Pasca Panen dilakukan setelah Kacang Tanah berumur 100 hari(3 bulan), hasil dari kacang yang dipanen kemudian disortir, bagian dari kacang tanah yang rusak dipisahkan dari bagian kacang tanah yang baik. Kacang tanah di jemur selama 3-4 hari. Kemudian akan dilakukan penyortiran tahap kedua. Setelah itu kacang tanah disimpan, dijual atau dikonsumsi.

Faktor Modal, Luas lahan, Benih, tenaga kerja, pengalaman usahatani, pendidikan petani secara bersama- sama (simultan) berpengaruh nyata terhadap produksi kacang tanah. secara sendiri- sendiri (parsial) faktor luas lahan, benih memiiki pengaruh yang positif dan signifikan terhadap produksi usahatani kacang tanah. sedangkan pngalaman usahatani, pendidikan, modal, tenaga kerja tidak berpengaruh terhadap produksi usahatani kacang tanah.

\section{Pustaka}

Badan Pusat Statistik Kabupaten TTU, 2014. TTU Dalam Angka 2014 Kefamenanu.

Darius, 2010. Sistem Pengembangan Agribisnis. Jakarta: Mutiara jakarta

Sapto, Husodo, 2004. Jurnal Ilmu - Ilmu Pertanian. STTP : Yogyakarta. Soekartawi, 2003. Teori Ekonomi Produksi. Dengan Pokok Bahasan Analisis. Fungsi Cobbdouglas. PT. Raja Grafindo Persada Jakarta.

Vyan. R.H., 2009.Kacang Tanah, Manfaat dan Dampaknya. Diakses pada 22 november 2015 . 